\title{
Information Value of the Segment Reporting in the Polish Energy Sector
}

\author{
Aleksandra Sulik-Górecka \\ University of Economics in Katowice, Poland
}

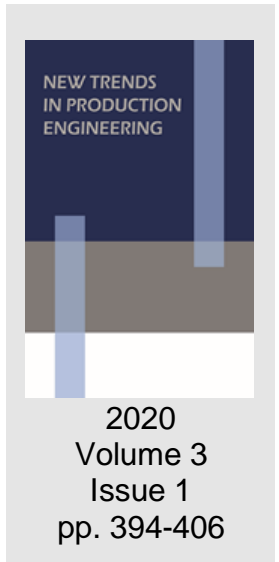

Date of submission to the Editor: 02/2020

Date of acceptance by the Editor: 03/2020

\section{INTRODUCTION}

The Polish energy sector is facing many challenges emerging from the need to modernize, among others, the existing transmission infrastructure as well as the construction of new energy sources. The European Union's requirements for reducing greenhouse gas emissions are a special challenge to meet. Due to the desire to halt global warming and the growing concern for the climate change, renewable energy sources are considered the future of energy. Poland is pursuing an energy policy in line with the European Union strategy, based on a steady increase in the share of energy produced from renewable sources, but lignite and hard coal still play a major role in ensuring energy security. The total installed capacity in coal-fired power plants accounts for over $69 \%$ of the installed capacity and $72.3 \%$ of the available capacity, while the production of electricity from these sources accounts for over $83 \%$ of the total production. In turn, renewable sources account for just over $7 \%$ of electricity production (Szczerbowski, Ceran, 2017). In accordance with Poland's energy policy, up to 2040, eight lines of action are planned (Olkuski, Grudziński, 2019):

1. Optimal use of energy resources.

2. Development of electricity generation and network infrastructure.

3. Diversification of gas and oil supplies and development of network infrastructure.

4. Development of energy markets.

5. Implementation of nuclear energy.

6. Development of renewable energy sources.

7. Development of heating and cogeneration.

8. Improvement of the energy efficiency of the economy.

The question arises whether the ongoing discussion on the above-mentioned issues, for example, the development of renewable energy sources and the diversification of the Polish energy sector are reflected in the annual financial reports of the key companies of the Polish energy sector. Do investors, based on financial statements, have the opportunity to obtain information about areas 
of diversification as well as assess the profitability of these areas and related risks? In order to meet investors' information needs regarding the valuable data presentation in the financial statements, there has been implemented, among others, the reporting obligation by operating segments.

The purpose of this study is to examine the content of financial statements regarding segment information and assess its suitability for shareholders. The assessment of segment disclosures was carried out in relation to the mandatory segment reporting requirements under International Financial Reporting Standards (abr. IFRS), particularly IFRS 8 "Operating segments".

\section{METHODOLOGY OF RESEARCH}

The study uses content analysis of the literature and legal acts. The empirical part uses the qualitative research method based on multiple case studies. A case study is a research method used to describe and test, and generalize the theory, thanks to which such features as innovation, testability and empirical validation due to the link with practice are obtained (Eisenhardt 1989).

In addition to the introduction, the structure of the study includes a description of reporting principles based on segments in accordance with IFRS and a summary of challenges facing the energy sector in Poland.

The empirical part of the paper analyzes the consolidated financial statements for 2018 of 10 company groups covered by the WIG ENERGY Index. Particular attention was paid to notes regarding operating segments and they were analyzed from the point of compliance with the requirements of IFRS 8. The area of analysis was also disclosed in terms of the risk of doing business in various areas.

\section{SEGMENT REPORTING BACKGROUND}

The financial statements present the outcomes of measuring the results achieved by reporting entities and are prepared, among others, to meet the information needs of investors and capital owners. Despite legal regulations determining the scope and detail of disclosures, the reporting policy depends on the company's Management Board, which, having the opportunity to choose the principles and methods of shaping business transactions and estimates, affects the quality of the financial statements (Sulik-Górecka, Strojek-Filus, Maruszewska, 2017).

Pursuant to the Regulation of the European Parliament and of the Council on the application of international accounting standards (European Parliament, 2002) a requirement was introduced for all EU listed companies regarding the preparation of consolidated financial statements in accordance with International Financial Reporting Standards (IFRS), starting from 2005'. The purpose of the regulation was to improve the transparency and comparability of company accounts. The effect of increasing comparability was

\footnotetext{
${ }^{1}$ IFRS together with International Accounting Standards (IAS) constitute a set of accounting standards, related interpretations and conceptual frameworks issued by the International Accounting Standards Board and implemented for the use in many countries.
} 
to increase the efficiency of market functioning and reduce the cost of raising capital for companies, which increases competitiveness and stimulates economic development in the European Union.

The scope of reports prepared according to IFRS is wider than those prepared according to the Polish Act on Accounting (2019). IFRS 8 "Operating segments" was issued by International Accounting Standards Board on 30 November 2006 and replaced previously binding IAS 34 - Interim Financial Reporting. IFRS 8 is mandatory for annual financial statements for periods beginning on or after 1 January 2009 (IFRS 8, 2006). According to IFRS 8, entities with publicly traded securities are required to include in the financial statements information about their operating segments, products and services, the geographical areas in which they operate, and their major customers. It should be noted that this information may be obtained from internal management reports.

The purpose of IFRS 8 was to provide users with information convergent with the information generated for the needs of the management board, i.e. from the management accounting system. The condition for separating segments according to IFRS 8 is also regular monitoring of segment results by the main responsible authority, which may be, but does not have to be, the entity's management board. The structure of the assessed financial data of operating segments is the factor affecting the form and scope of disclosures about segments in the financial statements. The negative effect of the adopted approach according to segments distinguished for operational needs is the diversity of reporting, which may hamper comparability for potential investors. The problem of quality of segment disclosure was widely analyzed in the literature (Bens et al, 2011; Nichols et al, 2012; Blanco et al, 2014, Zimnicki 2017).

There are two types of segments that IFRS 8 distinguishes: operating segments and reportable segments. An operating segment is defined as: "a component of an entity that engages in business activities from which it may earn revenues and incur expenses (including revenues and expenses relating to transactions with other components of the same entity) whose operating results are reviewed regularly by the entity's chief operating decision maker to make decisions about resources to be allocated to the segment and assess its performance and for which discrete financial information is available" (IFRS 8.2).

Reportable segments are operating segments or aggregations of operating segments that meet specified criteria (IFRS 8.13) Segments are distinguished when the value of sales revenues to external customers and between segments is at least $10 \%$ of the total value of revenues of all operating segments.

If quantitative criteria are not met for a given segment, it may be separately disclosed in the financial statements unless the management board decides otherwise. Legal regulations allow aggregation of segments into one, under certain conditions. The report should disclose the number of segments so that the sum of their revenues corresponds to $75 \%$ of the company's revenues. It should be emphasized that if this condition is not met, additional segments 
must be distinguished, even if the quantitative criteria for them are not satisfied (IFRS 8.15).

Two or more segments can be combined into one operating segment if the segments contain similar economic features and are similar in terms of analyzed issues (IFRS 8.12).

The basic parameters and requirements which, according to IFRS 8, should be disclosed in relation to each reporting segment are presented in Table 1.

Table 1 Disclosures regarding reporting segments in accordance with IFRS 8

\begin{tabular}{|c|c|}
\hline Disclosure type & Main Requirements \\
\hline $\begin{array}{l}\text { General } \\
\text { information } \\
\text { (IFRS 8.22) }\end{array}$ & $\begin{array}{l}\text { - method of identifying operating segments, e.g., by products } \\
\text { or services, geographical areas; } \\
\text { - type of products and services on which the reporting } \\
\text { segment generates its revenues; } \\
\text { - judgments made by management in applying the aggregation } \\
\text { criteria to allow two or more operating segments to be } \\
\text { aggregated. }\end{array}$ \\
\hline $\begin{array}{l}\text { Information about } \\
\text { the profit or loss } \\
\text { for each } \\
\text { reportable } \\
\text { segment } \\
\text { (IFRS } 8.21(\mathrm{~b}) \text {, } \\
23,24)\end{array}$ & $\begin{array}{l}\text { - revenue from external customers and from transactions with } \\
\text { other segments, } \\
\text { - interest revenue and expense, depreciation and amortization, } \\
\text { - income tax expense or income and material non-cash items } \\
\text { - a measure of total assets and total liabilities for each } \\
\text { reportable segment, } \\
\text { - } \text { amount of investments in associates and joint ventures }\end{array}$ \\
\hline $\begin{array}{l}\text { Explanation } \\
\text { of the principles } \\
\text { used } \\
\text { to measure } \\
\text { information } \\
\text { on operating } \\
\text { segments } \\
\text { IFRS } 8.27\end{array}$ & $\begin{array}{l}\text { - accounting policies for all transactions between reporting } \\
\text { segments, } \\
\text { - nature of any differences between the measurement of profit } \\
\text { or loss of reporting segments and the measurement of the } \\
\text { entity's gross profit or loss, } \\
\text { - nature of any differences between the measurement of the } \\
\text { assets of the reporting segments and the measurement } \\
\text { of the entity's assets, } \\
\text { - nature of any differences between the measurement } \\
\text { of liabilities of the reporting segments and the measurement } \\
\text { of the entity's liabilities } \\
\text { - nature and effect of any unsymmetrical allocations regarding } \\
\text { reporting segments }\end{array}$ \\
\hline $\begin{array}{l}\text { Reconciliations } \\
\text { to the financial } \\
\text { statements } \\
\text { IFRS } 8.21 \text { (b) } \\
\text { and } 28\end{array}$ & $\begin{array}{l}\text { - reconciliations of the totals of segment revenues, reported } \\
\text { segment profit or loss, segment assets, segment liabilities } \\
\text { and other material items to corresponding items in the } \\
\text { entity's financial statements }\end{array}$ \\
\hline $\begin{array}{l}\text { Entity-wide } \\
\text { disclosures IFRS } \\
8.32,33,34\end{array}$ & $\begin{array}{l}\text { - information about each product and service or groups } \\
\text { of products and services, } \\
\text { - } \text { analyses of revenues and certain non-current assets by } \\
\text { geographical area, } \\
\text { _ information about transactions with major customers }\end{array}$ \\
\hline
\end{tabular}

Source: own elaboration based on IFRS 8

Although the format of the disclosed data structure is not imposed by IFRS 8, reconciliations with other data from the financial statements should be disclosed, inter alia, in the scope of total revenues of reporting segments with revenues of the entire entity as well as total values of segment assets and liabilities with the value of assets and liabilities of the entire company. 
It should be noted that companies listed on the Polish stock exchange are required to publish non-financial information from 2018. This is the result of the implementation of Directive 2014/95/EU (European Parliament, 2014). The presentation of non-financial data may take the form of integrated reports. The idea of integrated reporting is to create one, joint report, which aims to indicate the process of creating value in the company (Chojnacka, 2014; Walińska et al., 2018; Piotrowska 2017). The main energy groups present in Poland are generally vertically integrated entities, controlling the full value chain from coal mining to the sale of energy, following global trends, they should be obliged to be responsible in every area of activity and to present comprehensive information on conducted activities (Woźniak, 2018).

The integrated reports may contain disclosures about the business model of the group and the identified operating segments; however, the integrated report should not replace the information required by IFRS 8 .

\section{ANALYSIS OF SEGMENT REPORTING IN COMPANY GROUPS FROM THE WIG_ENERGY INDEX}

In the face of the challenges, the energy sector companies are increasingly trying to diversify their activities. In order to examine the usefulness of information on the lines of diversification for the users of financial statements, the financial statements of companies listed on the Warsaw Stock Exchange included in the WIG_Energy index were analyzed. To prove the assumptions underlying this paper, the analysis carried out takes into account the consolidated financial statements for 2018 of the following groups of companies:

1. Company Group Elektrociepłownia "Bedzin" SA (BEDZIN, 2018),

2. CEZ Group (CEZ, 2018),

3. Company Group ENEA (ENEA, 2018),

4. Company Group Energa SA (ENERGA, 2018),

5. AB INTER RAO Lietuva (INTERAOLT, 2018),

6. Company Group Polenergia S.A. (PEP, 2018),

7. Company Group M.L. System S.A. (MLSYSTEM, 2018),

8. PGE Polska Grupa Energetyczna S.A. (PGE, 2018),

9. Company Group Tauron Polska Energia S.A. (TAURONPE, 2018),

10. Company Group Zespół Elektrowni Pątnów-Adamów-Konin S.A. (ZEPAK, 2018).

The purpose of the analysis was to verify whether the listed companies apply the principles used in internal reporting for management purposes to segment disclosures. In addition, the scope of disclosures about segments in the analyzed statements with the guidelines in IFRS 8 was compared.

Analyzing the information presented on the identification of segments, it should be noted that the most of the segments were identified in the CEZ and PEP groups -6 each. The smallest number of segments was separated in the BEDZIN group - only 2. In several groups there are very similar segments regarding: generation of energy, mining, distribution and sales. 
In some groups, the segment of energy generation is divided into production of energy from conventional sources and renewable sources as well. Separate segments of energy generation from unconventional sources were identified in the following analyzed groups: CEZ, INERAOLT, MLSYSTEM, PGE, PEP. Other often identified segments are shared services centers, e.g., IT, accounting, finance, logistics. In accordance with IFRS 8, the report should specify the rules for measuring information on operating segments. This obligation was not fulfilled in the following audited entities: BEDZIN, CEZ, ML SYSTEM, PGE, TAURON, ZEPAK. According to PEP disclosure: "The basis for assessing performance is operating profit or loss plus depreciation, which are measured differently from profit or loss on operating activities in the consolidated financial statements."

In the remaining audited entities, the rules used to measure the assets and liabilities, and performance of segments are "consistent with the principles applied for the purpose of preparing the consolidated financial statements" (ENEA, ENERGA, INTERAOLT). The requirements for the presentation of geographical segments are met by all entities except for ML SYSTEM. The most geographically dispersed activity is conducted by CEZ (Czechia, Germany, Poland, France, Romania, Bulgaria) TAURON (Poland, Czech Republic, Slovakia, the UK, Luxemburg, Austria, Hungary) and PGE (Poland, the EU, other).

Undoubtedly, the synthetic financial information presented in Table 2 Part 1 and Part 2 shows the greatest information value for shareholders.

Table 2 Selected segment disclosures in financial statements of WIG_Energy companies Part 1

\begin{tabular}{|c|c|c|c|c|c|c|c|}
\hline \multirow[b]{2}{*}{$\begin{array}{l}\text { Company } \\
\text { group }\end{array}$} & \multirow[b]{2}{*}{$\begin{array}{c}\text { Number } \\
\text { of segments }\end{array}$} & \multicolumn{4}{|c|}{ Financial Data } & \multicolumn{2}{|c|}{ Ratios } \\
\hline & & Revenues & $\begin{array}{c}\text { Net } \\
\text { Income }\end{array}$ & Assets & Liabilities & $\begin{array}{l}\text { Return } \\
\text { on sale }\end{array}$ & $\begin{array}{c}\text { Return } \\
\text { on } \\
\text { assets }\end{array}$ \\
\hline $\begin{array}{l}\text { BEDZIN PLN } \\
\text { thousand }\end{array}$ & $\begin{array}{l}\text { 1. Energy } \\
\text { segment } \\
\text { (generation } \\
\text { of energy from } \\
\text { conventional } \\
\text { sources) } \\
2 \text {. Finance } \\
\text { segment } \\
\text { (leases of } \\
\text { tangible assets) } \\
\end{array}$ & 182947 & -2156 & 378156 & 370570 & $-6.8 \%$ & $-0.6 \%$ \\
\hline \multirow{6}{*}{$\begin{array}{l}\text { CEZ CZK } \\
\text { milion }\end{array}$} & $\begin{array}{l}\text { 1. Generation - } \\
\text { Traditional } \\
\text { Energy }\end{array}$ & 87388 & 25945 & 246206 & \multirow{6}{*}{$\begin{array}{c}\text { no data } \\
\text { available }\end{array}$} & $29.7 \%$ & $10.5 \%$ \\
\hline & $\begin{array}{l}\text { 2. Generation - } \\
\text { New Energy }\end{array}$ & 6099 & 1276 & 27392 & & $20.9 \%$ & $4.7 \%$ \\
\hline & 3. Distribution & 40944 & 10619 & 109741 & & $25.9 \%$ & $9.7 \%$ \\
\hline & 4. Sales & 85693 & 3062 & 3838 & & $3.6 \%$ & $79.8 \%$ \\
\hline & 5. Mining & 9532 & 1632 & 20062 & & $17.1 \%$ & $8.1 \%$ \\
\hline & 6. Other & 16518 & -105 & 9286 & & $-0.6 \%$ & $-1.1 \%$ \\
\hline \multirow{4}{*}{$\begin{array}{l}\text { ENEA PLN } \\
\text { thousand }\end{array}$} & 1. Sales & 8968988 & -76982 & 1466651 & 457893 & $-0.9 \%$ & $-5.2 \%$ \\
\hline & 2. Distribution & 2727891 & 574865 & 9335105 & 525925 & $21.1 \%$ & $6.2 \%$ \\
\hline & 3. Generation & 7171146 & 498804 & 10146901 & 950997 & $7.0 \%$ & $4.9 \%$ \\
\hline & 4. Mining & 1756673 & 105448 & 3025897 & 294605 & $6.0 \%$ & $3.5 \%$ \\
\hline
\end{tabular}




\begin{tabular}{|c|c|c|c|c|c|c|c|}
\hline & $\begin{array}{l}\text { 5. Other, eg.: } \\
\text { maintenance } \\
\text { of road lighting } \\
\text { equipment, } \\
\text { transport } \\
\text { services, } \\
\text { construction } \\
\text { services }\end{array}$ & 603504 & 19510 & 497438 & 280701 & $3.2 \%$ & $3.9 \%$ \\
\hline \multirow[b]{4}{*}{$\begin{array}{l}\text { ENERGA } \\
\text { PLN milion }\end{array}$} & 1. Distribution & 4028 & 647 & 13890 & 4550 & $16.1 \%$ & $4.7 \%$ \\
\hline & 2. Sales & 5529 & -100 & 2379 & - & $-1.8 \%$ & $-4.2 \%$ \\
\hline & 3. Generation & 1256 & 306 & 4556 & 920 & $24.4 \%$ & $6.7 \%$ \\
\hline & $\begin{array}{l}\text { 4. Other } \\
\text { (shared } \\
\text { services } \\
\text { centres, eg.: } \\
\text { IT, accounting, } \\
\text { finance, } \\
\text { logistics) }\end{array}$ & 629 & 462 & 16108 & 7641 & $73.4 \%$ & $2.9 \%$ \\
\hline \multirow[b]{2}{*}{$\begin{array}{l}\text { INTERAOLT } \\
\text { EUR } \\
\text { thousand }\end{array}$} & $\begin{array}{l}\text { 1. Purchase } \\
\text { and sales of } \\
\text { electricity }\end{array}$ & 283913 & 13837 & 38825 & 32214 & $4.9 \%$ & $35.6 \%$ \\
\hline & $\begin{array}{l}\text { 2. Production } \\
\text { and sales of } \\
\text { electricity } \\
\text { (electricity is } \\
\text { produced by } \\
\text { wind turbines) }\end{array}$ & 4356 & 1097 & 22850 & 9505 & $25.2 \%$ & $4.8 \%$ \\
\hline \multirow{6}{*}{$\begin{array}{l}\text { PEP PLN } \\
\text { thousand }\end{array}$} & $\begin{array}{l}\text { 1. Wind } \\
\text { energetics }\end{array}$ & 149093 & 51277 & 1279535 & 900184 & $34.4 \%$ & $4.0 \%$ \\
\hline & $\begin{array}{l}\text { 2. Conventional } \\
\text { energetics, } \\
\text { heat and } \\
\text { electricity } \\
\text { production }\end{array}$ & 348104 & 86161 & 267236 & 86812 & $24.8 \%$ & $32.2 \%$ \\
\hline & $\begin{array}{l}\text { 3. Marketing } \\
\text { and sales } \\
\text { of energy }\end{array}$ & 2843241 & -22527 & 814570 & 770389 & $-0.8 \%$ & $-2.8 \%$ \\
\hline & 4. Distribution & 86181 & 8033 & 126648 & 71368 & $9.3 \%$ & $6.3 \%$ \\
\hline & $\begin{array}{l}\text { 5. Biomass, } \\
\text { eg.: pellet } \\
\text { production from } \\
\text { energy crops }\end{array}$ & 17821 & -32646 & 11832 & 5694 & $-183.2 \%$ & $-275.9 \%$ \\
\hline & $\begin{array}{l}\text { 6. Developer } \\
\text { activities, eg.: } \\
\text { construction } \\
\text { of wind farms } \\
\text { and power } \\
\text { plant }\end{array}$ & 7 & -8923 & 78879 & 2663 & $\begin{array}{c}127471.4 \\
\%\end{array}$ & $-11.3 \%$ \\
\hline
\end{tabular}

Source: Own elaboration

It should be noted that CEZ and ZEPAK do not disclose information about the liabilities of individual segments, which does not allow investors to find out about the debt of individual areas, and only ENEA disclosed financial liabilities attributable to individual segments. ZEPAK also did not disclose data on the value of assets involved in individual segments, which is not in line with IFRS 8. PGE presented segment assets without trade receivables. There are differences in the presentation of profit. The net sales result for ENEA, operating profit segment for INTERRAO, gross profit for Polenerga, EBIT for PGE were disclosed. 
Table 2 Selected segment disclosures in financial statements of WIG_Energy companies Part 2

\begin{tabular}{|c|c|c|c|c|c|c|c|}
\hline \multirow[b]{2}{*}{$\begin{array}{c}\text { Company } \\
\text { group }\end{array}$} & \multirow[b]{2}{*}{$\begin{array}{c}\text { Number } \\
\text { of segments }\end{array}$} & \multicolumn{4}{|c|}{ Financial Data } & \multicolumn{2}{|c|}{ Ratios } \\
\hline & & Revenues & $\begin{array}{c}\text { Net } \\
\text { Income }\end{array}$ & Assets & Liabilities & $\begin{array}{l}\text { Return } \\
\text { on sale }\end{array}$ & $\begin{array}{l}\text { Return } \\
\text { on } \\
\text { assets }\end{array}$ \\
\hline \multirow{3}{*}{$\begin{array}{l}\text { MLSYST } \\
\text { EM } \\
\text { PLN } \\
\text { thousand }\end{array}$} & \multirow{3}{*}{$\begin{array}{l}\text { 1. Production, } \\
\text { service related } \\
\text { to photovoltaics } \\
\text { 2. Production, } \\
\text { service related } \\
\text { to photovoltaics } \\
\text { 3. Research and } \\
\text { development } \\
\end{array}$} & 21611 & 2501 & 32 & 0 & $11.6 \%$ & $7815.6 \%$ \\
\hline & & 104543 & 8788 & 143944 & 76171 & $8.4 \%$ & $6.1 \%$ \\
\hline & & 5045 & -1279 & 1121 & 1829 & $-25.4 \%$ & $-114.1 \%$ \\
\hline \multirow{5}{*}{$\begin{array}{l}\text { PGE } \\
\text { PLN } \\
\text { milion }\end{array}$} & \multirow{5}{*}{$\begin{array}{l}\text { 1. Conventional } \\
\text { energetics, eg.: } \\
\text { extraction of brown } \\
\text { coal } \\
\text { 2. Generation } \\
\text { of renewable energy } \\
\text { 3. Sales } \\
\text { 4. Distribution } \\
\text { 5. Other (shared } \\
\text { services centres, } \\
\text { eg.: IT, accounting, } \\
\text { finance, logistics) } \\
\end{array}$} & 16644 & 564 & 46631 & 10959 & $3.4 \%$ & $1.2 \%$ \\
\hline & & 839 & 205 & 3191 & 417 & $24.4 \%$ & $6.4 \%$ \\
\hline & & 14377 & 238 & 1400 & 2048 & $1.7 \%$ & $17.0 \%$ \\
\hline & & 5878 & 2463 & 17767 & 2051 & $41.9 \%$ & $13.9 \%$ \\
\hline & & 615 & 81 & 659 & 133 & $13.2 \%$ & $12.3 \%$ \\
\hline \multirow{5}{*}{$\begin{array}{l}\text { TAURON } \\
\text { PE PLN } \\
\text { thousand }\end{array}$} & \multirow{5}{*}{$\begin{array}{l}\text { 1. Coal mining } \\
\text { 2. Generation } \\
\text { of energy from } \\
\text { renewable and non- } \\
\text { renewable sources } \\
\text { 3. Distribution } \\
\text { 4. Sales } \\
\text { 5. Other eg.: stone } \\
\text { mining of limestion } \\
\text { for energetics, } \\
\text { metallurgy, } \\
\text { construction }\end{array}$} & 1266024 & 1053469 & 1589823 & 851497 & $-83.2 \%$ & $-66.3 \%$ \\
\hline & & 4638494 & 196658 & 12712861 & 1299850 & $4.2 \%$ & $1.5 \%$ \\
\hline & & 6158215 & 1417102 & 18345603 & 2152473 & $23.0 \%$ & $7.7 \%$ \\
\hline & & 14074115 & 306481 & 3379688 & 1753298 & $2.2 \%$ & $9.1 \%$ \\
\hline & & 857462 & 46023 & 581497 & 410567 & $5.4 \%$ & $7.9 \%$ \\
\hline \multirow{5}{*}{$\begin{array}{l}\text { ZEPAK } \\
\text { PLN } \\
\text { thousand }\end{array}$} & $\begin{array}{l}\text { 1. Electricity } \\
\text { generation from } \\
\text { conventional sources } \\
\text { and from biomass }\end{array}$ & 2096382 & -208130 & \multirow{5}{*}{$\begin{array}{c}\text { no data } \\
\text { available }\end{array}$} & \multirow{5}{*}{$\begin{array}{c}\text { no data } \\
\text { available }\end{array}$} & $-9.9 \%$ & \multirow{5}{*}{$\begin{array}{c}\text { no data } \\
\text { available }\end{array}$} \\
\hline & 2. Lignite mining & 814506 & -248903 & & & $-30.6 \%$ & \\
\hline & $\begin{array}{l}\text { 3. Renovation eg.: } \\
\text { services in the area } \\
\text { of construction and } \\
\text { renovation services }\end{array}$ & 276327 & -326 & & & $-0.1 \%$ & \\
\hline & 4. Sales & 575831 & -14240 & & & $-2.5 \%$ & \\
\hline & 4. Other & 168719 & 5592 & & & $3.3 \%$ & \\
\hline
\end{tabular}

Source: Own elaboration

Comparing the value of assets involved in individual types of segments, in such groups as CEZ, ENEA, and PGE, the highest value of assets is involved in segments related to traditional energy. At TAURON, ENERGA and INTERAOLT, most of the assets were involved in the distribution segment. Only PEP presented the highest value of assets involved falling to the "Wind Energy" segment. 
Analyzing the value of achieved profits, the most of the profits were realized in energy generation segments from traditional sources in such groups as: BEDZIN, ML SYSTEN, PEP. It should be noted that the PEP profit realized on the production of energy from wind is at the level of $60 \%$ of the profit realized from the production of energy from traditional sources. In groups such as TAURONPE, PGE, ENERGA and ENEA, the distribution segment generates the largest profits. Only MLSYSTEM, focused on other energy sources than traditional, realized the largest profit, for example, on production, service and commercial activities related to photovoltaics. A negative result on the production of energy from unconventional sources was shown by PEP (biomass segment) and ZEPAK only, in which the entity generally realizes a loss on all segments. Negative or very low results were shown in mining related segments, this applies to entities such as: TAURONPE, ZEPAK, CEZ, ENEA. The segments identified as "sales" showed negative results in such groups as: ENEA, ENERGA, PEP.

For the purposes of the study, the return on sales ratio was calculated, measuring the value of the result presented in the segment to the sales revenues of this segment. Profitability ratios for sales of segments related to energy production from traditional sources range from minus $9.9 \%$ in the lossmaking ZEPAK, $2.7 \%$ in BEDZIN, 3.4\% in PGE, 7\% in ENEA $24.4 \%$ in ENERGA, 24, $8 \%$ in PEP up to $29.7 \%$ in CEZ.

Profitability ratios for sales of segments related to the production of energy from unconventional sources are the highest in PEP - 34.4\% (Wind energy segment) and PGE $-24.4 \%$ and in CEZ - 20.9\%. Profitability ratios of distribution segments are from $9.3 \%$ in PEP, $16.1 \%$ in ENERGA, $21.1 \%$ in ENEA, 23\% in TAURONPE to $41.9 \%$ in PGE.

Asset profitability ratios were also calculated, which often take the highest values for sales related segments, e.g., $35.6 \%$ in INTERAOLT, $79.8 \%$ in CEZ, $17 \%$ in PGE, $9.1 \%$ in TAURONPE.

It is difficult to find information on the identified risks assigned to the segments in the notes covering segment data. Such disclosure is provided by BEDZIN, where the main risk was identified in the form of sales to one main customer which is TAURONPE as well as seasonality in energy sales, heat sale price risk for the energy generation from conventional sources segment. Moreover, the main risk for finance segment providing leases of tangibles was connected with leasing receivables.

The financial statements of PGE drew attention to factors affecting the technical and economic conditions for the production and distribution of energy carriers, and thus affecting the financial results obtained. These factors include: atmospheric factors (air temperature, wind strength, amount of precipitation), socioeconomic factors (number of energy consumers, prices of energy carriers, economic development of GDP) and technological factors (technological progress, technology of product manufacture). In the heat sales segment, seasonality effects are more important for households than for the industrial sector. Meteorological conditions are particularly important for energy 
production in the renewable energy segment, where electricity is generated from natural resources such as water, wind, sun.

However, the other financial statements disclose risks for the entire company group that arise from certain areas of business. For example, CEZ identifies the operational risk of nuclear and fossil power plants operation in the Czech Republic as well as the risk of provision for mine reclamation and mining damages and waste storage reclamation. As part of market risks, financial risk (e.g. currency, interest and stock price), risk of commodity prices (e.g. electricity, emission allowances, coal, gas, crude oil) and risk of volume (e.g. volume of electricity produced by wind power plants).

The ENEA group disclosed risks in another context, primarily identifying credit risk associated with the potential inability to obtain receivables from contractors. The factors affecting this risk include, first of all, a large number of recipients facing difficulties in assessing the creditworthiness of contractors and the amount of costs of controlling the date of receipt and the cost of collecting debts. The specific risk is also generated by legal conditions of the conducted activity, defining, among others, the performance of the function of a reserve seller or an ex-officio seller, mandatory connection of entities from a given distribution area as well as the rules of suspending the supply of electricity due to non-payment. In the ENEA group, a significant commodity risk is caused by the fact that the Group buys energy at market prices, while it calculates its tariff based on costs recognized by the President of the Energy Regulatory Office as justified and taking into account the margin (in turnover) planned for the next tariff period. There is a limited possibility of transferring unfavorable changes in the costs of its activities to final consumers of electricity. Due to the need to purchase $\mathrm{CO}_{2}$ emission allowances and the provision of services by contractors whose prices/costs are denominated in Euro, the group is also exposed to the currency risk.

Risk disclosures in the ENERGA group relate primarily to the risk of changes in WIBOR interest rates, mainly related to long-term financial debt. The Group also identifies the risk of changes in electricity purchase prices and certificates of origin on the wholesale market.

\section{CONCLUSION}

The purpose of IFRS 8 is to provide information in a manner that allows users of financial statements to evaluate the type and financial effects of economic activities in which the entity is involved and the economic environment in which it operates. The issues are particularly important for enterprises in the energy sector, which are somewhat forced to diversify their activities towards, e.g., production of energy from renewable sources. Despite the requirements arising from the EU law and the Polish Energy Policy, for the analyzed companies from the WIG_ENERGY index, the segments of energy generation from conventional sources (BEDZIN, ML SYSTEN, PEP) and distribution (TAURONPE, PGE, ENERGA and ENEA). Profitability ratios for sales of segments related to the production of energy from unconventional sources are, however, at a fairly high 
level, e.g., in PEP - 34.4\% (wind energy segment), PGE - $24.4 \%$ and in CEZ $20.9 \%$. A negative result on the production of energy from unconventional sources was shown only by PEP (biomass segment) and ZEPAK, in which the entity generally realizes a loss on all segments. It is a mining related segment, generating negative or very low results (e.g. TAURONPE, ZEPAK, CEZ, ENEA). As a result of the analysis, it was found that, a large variety of information on published segments should be stated, despite the fact that the audited company groups belong to one sector. Differences were observed in both segment identification, segment measurement principles, presentation of assets and liabilities. Some of the requirements of IFRS 8 were not met at all. The business risk is only slightly disclosed in relation to the individual segments identified. Such diversity may cause difficulties in making comparisons between companies as well as in making investment decisions by shareholders.

\section{REFERENCES}

Act on Accounting. Act of 29 September, 1994 on Accounting. Journal of Laws 2019 item 351, as amended. [online]. Available at: http://prawo.sejm.gov.pl/isap.nsf/download.xsp/WDU20180000395/O/D2018039 5.pdf [Accessed: 10 March 2020].

BEDZIN (2018), Consolidated Financial Statement for 2018. [online]. Available at: http://www.ecbedzin.pl/resources/2019/Raporty_okresowe/RS_2018_GK_ECB_ S.A._17_05_2019_uzupelnione_www_all.pdf [Accessed: 10 March 2020].

Bens D. A., Berger P. G., Monahan S. J. (2011) Discretionary Disclosure in Financial Reporting: An Examination Comparing Internal Firm Data to Externally Reported Segment Data. The Accounting Review: March 2011, 86(2) pp. 417-449. [online]. Available at: https://doi.org/10.2308/accr.00000019 [Accessed: 10 March 2020].

Blanco B., Lara,J. M. G., Tribo J. (2014). The relation between segment disclosure and earnings quality. J. Account. Public Policy, 33, pp. 449-465. [online]. Available at: https://doi.org/10.1016/j.jaccpubpol.2014.06.002 [Accessed: 10 March 2020]

CEZ (2018), Consolidated Financial Statement for 2018. [online]. Available at: https://www.cez.cz/en/investors/financial-reports/annual-reports.html [Accessed: 10 March 2020].

Chojnacka E. (2014). Raportowanie danych w obszarach środowiskowym i społecznym w publicznych spółkach sektora energetycznego. Prace Naukowe Uniwersytetu Ekonomicznego we Wrocławiu, 329, pp. 45-53 [online]. Available at: https://www.ceeol.com/search/article-detail?id=223263 [Accessed: 10 March 2020].

Eisenhardt, K.M., (1989), Building theories from case study research. Academy of management review, 14(4), pp. 532-550. http://www.jstor.org/stable/10.2307/258557 [Accessed: 10 March 2020].

Enea (2018), Consolidated Financial Statement for 2018. [online]. Available at: https://ir.enea.pl/pr/427942/skonsolidowany-raport-roczny-rs-2018 [Accessed: 10 March 2020]ENERGA (2018), Consolidated Financial Statement for 2018. [online]. Available at: https://ir.energa.pl/pr/426660/skonsolidowane-wynikifinansowe-za-2018-rok [Accessed: 10 March 2020].

European Parliament (2002), Regulation No 1606/2002 of the European Parliament and of the Council of 19 July 2002 on the application of international accounting standards. [online]. Available at: https://op.europa.eu/en/publication-detail//publication/063990c7-2ce2-4e5c-b0cc-5eba713d7d08/language-en/format-

PDF/source-119380130 [Accessed: 10 March 2020].

European Parliament (2014), Directive 2014/95/EU of the European Parliament and of the Council of 22 October 2014 amending Directive 2013/34/EU as regards 
disclosure of non-financial and diversity information by certain large undertakings and groups. [online]. Available at: https://eur-lex.europa.eu/legalcontent/EN/TXT/?uri=CELEX\%3A32014L0095 [Accessed: 10 March 2020].

IFRS 8 (2006), International Financial Reporting Standard (IFRS) 8 Operating segments, IASB. [online]. Available at: https://www.ifrs.org [Accessed: 10 March 2020].

INTERAOLT (2018), Consolidated Financial Statement for 2018. [online]. Available at: https://interrao.It/app/uploads/2019/02/IRL-Consolidated-Annual-Report-

Financial-Statements-and-Auditor-Report-2018.pdf [Accessed: 10 March 2020].

Nichols, N. B., Street, D. L., \& Cereola, S. J. (2012). An analysis of the impact of adopting IFRS 8 on the segment disclosure of European blue chip companies. Journal of Accounting, Auditing, and Taxation, 21, 79-105. [online]. Available at: https://www.sciencedirect.com/science/article/abs/pii/S1061951812000171 [Accessed: 10 March 2020].

MLSYSTEM (2018), Consolidated Financial Statement for 2018. [online]. Available at: https://ir.mlsystem.pl/wp-

content/uploads/2019/03/Skonsolidowane_roczne_SF_MLSA_2018_final.pdf [Accessed: 10 March 2020].

Olkuski T., Grudziński Z. (2019), Polityka energetyczna Polski - nowe wyzwania, Zeszyty Naukowe Instytutu Gospodarki Surowcami Mineralnymi i Energią Polskiej Akademii Nauk, 108, pp. 71-82. [online]. Available at: DOI:10.24425/znigsme.2019.128670 [Accessed: 10 March 2020].

PEP (2018), Consolidated Financial Statement for 2018. [online]. Available at: https://www.polenergia.pl/pol/sites/default/files/reports/periodical/grupa_polener gia_s.a._sprawozdanie_skonsolidowane.pdf [Accessed: 10 March 2020].

PGE (2018), Consolidated Financial Statement for 2018. [online]. Available at: https://www.gkpge.pl/relacje-inwestorskie/Materialy-do-pobrania?rok=2019 [Accessed: 10 March 2020].

Piotrowska, A. (2017). Specyfika sprawozdawczości spółek giełdowych na przykładzie spółek sektora energetycznego. Gospodarka w Praktyce I Teorii, 49(4), 69-82. [online]. Available at: https://doi.org/10.18778/1429-3730.49.05 [Accessed: 10 March 2020].

Sulik-Gorecka, M. Strojek-Filus, E. Maruszewska. (2017) "IFRS valuation models vs. business entities' practice - a case of Polish publicly traded enterprises", European Financial Systems 2017. Proceedings of the 14th International Scientific Conference. Part II, June 26-27, 2017 Brno, Czech Republic, ed. J. Nesleha, T. Plihal, K. Urbanovsky, pp. 356-364. [online]. Available at: https://is.muni.cz/do/econ/sborniky/70896034/EFS2017-Proceedings_2_final.pdf Accessed: 10 March 2020].

Szczerbowski R, Ceran B. (2017), Polityka energetyczna Polski w aspekcie wyzwań XXI wieku, Polityka Energetyczna - Energy Policy Journal, Tom 20, Zeszyt 3, pp. 17-28. [online]. Available at: http://journals.pan.pl/dlibra/publication/122666/edition/106934/content/politykaenergetyczna-polski-w-aspekcie-wyzwan-xxi-wieku-szczerbowski-radoslawceran-bartosz?language $=$ en [Accessed: 10 March 2020].

TAURONPE (2018), Consolidated Financial Statement for 2018. [online]. Available at: https://www.tauron.pl/tauron/relacje-inwestorskie/raporty-okresowe [Accessed: 10 March 2020].

Walińska E., Bek-Gaik B., Gad J.(2018) Informacje finansowe i niefinansowe w raporcie zintegrowanym - praktyka spółek notowanych na Giełdzie Papierów Wartościowych w Warszawie, Zeszyty Teoretyczne Rachunkowości, pp. 167190. [online]. Available at: https://www.ceeol.com/search/articledetail?id=725462 [Accessed: 10 March 2020].

Woźniak J. (2018), Dobre praktyki raportowania danych niefinansowych podmiotów zintegrowanych pionowo w energetycznym łańcuchu wartości, Polityka Energetyczna - Energy Policy Journal, 21(1) pp. 143-154. [online]. Available at: 
http://journals.pan.pl/dlibra/publication/122637/edition/106907/content/dobrepraktyki-raportowania-danych-niefinansowych-podmiotow-zintegrowanychpionowo-w-energetycznym-lancuchu-wartosci-wozniak-justyna?language=pl [Accessed: 10 March 2020].

ZEPAK (2018), Consolidated Financial Statement for 2018. [online]. Available at: https://ri.zepak.com.pl/pl/raporty/raporty-okresowe/1268-skonsolidowany-raportroczny-grupy-ze-pak-sa-za-2018-rok.html [Accessed: 10 March 2020].

Zimnicki T. (2017) The relevance of segment reports - measurement methodology, Zeszyty Teoretyczne Rachunkowości, Stowarzyszenie Księgowych, 93(149), 2017, pp. 253-278. [online]. Available at: http://yadda.icm.edu.pl/yadda/element/bwmeta1.element.desklight-f4eaaa14f411-4a33-a1dc-c8c2b8fed6a4/c/16_B5_Zimnicki.pdf [Accessed: 10 March 2020].

\begin{abstract}
.
Conventional energy sources dominate in the Polish energy sector, which is a huge risk to meeting environmental protection requirements. Polish energy companies are facing challenges related to meeting the requirements of the European Union and the National Energy Policy. The paper attempts to answer the question whether the ongoing discussion on the future of the energy sector, dealing with such issues as development of renewable energy sources is reflected in the annual financial reports of companies listed on the Warsaw Stock Exchange and covered by the WIG_ENERGY index. This study contributes to the extant literature on financial disclosures in several ways. First, the examination of compliance of segment reporting of selected companies listed on the Polish stock exchange with International Reporting Standards (IFRS) was carried out (particularly IFRS 8 - Operating Segments). Second, the information value of disclosures for investors in the energy industry was assessed. The empirical part was preceded by a description of segment reporting principles in accordance with IFRS 8 and the summary of challenges facing the energy sector in Poland.
\end{abstract}

Keywords: segment reporting, IFRS 8, shareholders, earnings quality, energy sector 